\title{
Media Pembelajaran dengan Kecerdasan Buatan dalam Pembelajaran Bahasa Inggris Generasi-Z
}

\author{
Ni Luh Putu Ning Septyarini Putri Astawa ${ }^{1}$, Putu Trisna Hady Permana ${ }^{2}$ \\ Sistem Informasi, STMIK Primakara, Indonesia ${ }^{1}$ \\ Teknik Informatika, STMIK Primakara, Indonesia ${ }^{2}$ \\ Email corresponding author: ningseptyarini@ymail.com
}

\begin{abstract}
ABSTRAK
Penelitian ini bertujuan untuk mengembangkan sebuah purwa-rupa media pembelajaran Bahasa Inggris berbasis kecerdasan buatan untuk siswa kelas VIII SMPN 5 Mengwi, Bali. Adapun konten materi yang ditentukan dalam penelitian ini adalah teks deskripsi hewan endemik Indonesia. Penelitian ini menggunakan desain Research and Development ADDIE. Dalam model ADDIE terdiri 5 tahapan penelitian yang dilakukan, diantaranya tahap Analisis (Analysis), Desain (Design), Pengembangan (Development), Implementasi (Implementation), dan Evaluasi (Evaluation). Namun, peneliti hanya melaksanakan penelitian ini sampai dengan tahapan pengembangan mengingat terbatasnya waktu yang tersedia. Data penelitian diperoleh dari hasil kuesioner, interview, dan validasi ahli materi dan media. Pada observasi awal ditemukan bahwa 96.1\% siswa berumur 13-15 tahun di Kabupaten Badung terbiasa dengan penggunaan teknologi dalam kehidupan sehari-hari. Hal ini menunjukan kedekatan mereka sebagai generasi $\mathrm{Z}$ terhadap penerapan teknologi dalam segala aspek kehidupan mereka, termasuk dalam proses belajar-mengajar. Oleh karena itu, dirasa perlu untuk peneliti mengembangkan sebuah media pembelajaran berbasis teknologi yang dapat mendukung guru dalam mengajar siswa yang juga adalah generasi z. Teknologi kecerdasan buatan digunakan dalam penelitian ini dengan melihat penelitian sebelumnya yang mengungkapkan keuntungan yang dapat diperoleh dalam pengimplementasiannya di dalam kelas. Di akhir pembelajaran, dari segi materi ditemukan bahwa purwa-rupa dari media pembelajaran yang dirancang memiliki kualitas yang sangat baik dengan nilai 84. Penelitian ini pula dinilai dapat menciptakan purwa-rupa yang memiliki kualitas sangat baik dari segi media dengan total nilai akhir 85 .
\end{abstract}

Kata Kunci: Generasi-Z, Hewan Endemik Indonesia , Kecerdasan Buatan

\section{PENDAHULUAN}

Generasi-Z atau yang biasa juga disebut dengan generasi digital native adalah generasi yang terlahir di antara tahun 1996 sampai dengan 2009 atau tepatnya saat telah tersedianya teknologi di kehidupan kita (Rastati, 2018). Para generasi-z juga disebut dengan generasi digital natives karena kemampuan dan kesiapannya dalam menggunakan perangkat teknologi. Tapscott (2013) menyatakan bahwa para generasi digital natives dapat menggunakan teknologi sama alaminya seperti bernafas. Mereka melakukan banyak hal melalui teknologi, seperti mencari sumber belajar untuk tugas sekolah, bersosial media, bermain game, hingga sekedar mencari informasi di internet. Hal tersebut juga didukung oleh hasil pre-observasi yang telah dilakukan oleh peneliti 
yang dimana ditemukan bahwa 96.1\% dari 203 orang siswa berumur 13-15 tahun di Kabupaten Badung Bali menyatakan kesiapan dan kedekatan mereka dengan penggunaan teknologi dalam kehidupannya sehari-hari. Sesuai dengan paham kemampuan belajar abad 21, teknologi memiliki peranan yang amat penting dalam proses belajar mengajar (Henriksen, Mishra, \& Fisser, 2016). Hal tersebut menjadi sebuah tantangan tersendiri bagi guru masa kini. Guru harus mampu menjawab tantangan tersebut dengan cara mampu memahami dan menyediakan media pembelajaran berbasis teknologi agar sesuai dengan kebutuhan dan minat siswa generasi-z.

Salah satu teknologi yang dipercaya memiliki potensi yang sangat baik kedepannya di dalam dunia pendidikan adalah teknologi kecerdasan buatan (Chassignol dkk., 2018). Menurut Ma dkk. (2014), kecerdasan buatan adalah sebuah sistem yang dikembangkan untuk dapat mampu melakukan tugas-tugas selayaknya manusia, seperti persepsi visual, pengenalan suara, pengambil keputusan, dan terjemahan antar bahasa. Terdapat beberapa studi yang sudah dilaksanakan mengenai kecerdasan buatan dalam dunia pendidikan. Terdapat beberapa jenis kecerdasan buatan yang diaplikasikan di dunia pendidikan, salah satunya adalah dual teacher classroom. Dual teacher classroom adalah keadaan dimana terdapat dua guru di dalam kelas, yaitu guru kelas pada umumnya dan guru berbasis kecerdasan buatan (Deloitte, 2019). Guru berbasis kecerdasan buatan bertugas untuk membantu proses belajar mengajar. Berbeda dengan guru konvensional, guru berbasis kecerdasan buatan dipercaya dapat memberikan asistensi kepada siswa terhadap pembelajaran secara efisien (Fahimirad \& Kotamjani, 2018). Keberadaan sistem cerdas ini diharapkan dapat memberikan bantuan kepada guru untuk menjawab pertanyaanpertanyaan siswa sembari tetap fokus terhadap hal yang bersifat prinsipil seperti memikirkan metode pengajaran yang akan digunakan di kelas berikutnya.

Penggunaan sistem kecerdasan buatan di dalam proses pembelajaran juga dipercaya dapat meningkatkan kemampuan siswa dalam melakukan proses pembelajaran yang mandiri. Murphy (2019) menyatakan bahwa dengan menggunakan sistem kecerdasan pada pendidikan, dapat membuat siswa untuk melakukan kegiatan belajar yang aktif dan mandiri. Hal ini sesuai dengan konsep pendidikan abad 21 yang berfokus pada peran siswa di dalam pembelajaran. Oleh karena manfaat yang dapat diperoleh, peneliti memutuskan untuk menggunakan kecerdasan buatan dalam studi kali ini.

Dalam penelitian ini, peneliti berfokus pada perancangan sebuah purwa-rupa media pembelajaran berbasis kecerdasan buatan yang dapat memfasilitasi siswa dalam belajar Bahasa Inggris. Adapun tema atau topik dipilih berdasarkan saran dari guru Bahasa Inggris kelas VIII SMPN 5 Mengwi. Tema yang dipilih adalah teks deskriptif dengan topik hewan endemik Indonesia. Hewan endemik adalah hewan yang hidup disuatu daerah yang dimana tidak dapat ditemukan di wilayah lain 
(Aristides, Purnomo, \& Samekto, 2016). Topik ini dipilih berdasarkan pertimbangan antara guru dan peneliti dengan tujuannya untuk mengembangkan potensi daerah yang dimiliki di Indonesia. Purwarupa dari media pembelajaran berbasis kecerdasan buatan ini diharapkan mampu memberikan pengalaman belajar Bahasa Inggris yang berbeda secara mandiri kepada siswa kelas VIII SMPN 5 Mengwi.

\section{METODE PENELITIAN}

Peneliti menggunakan metode Penelitian dan Pengembangan ADDIE. ADDIE adalah sebuah singkatan dari Analysis (analisis), Design (desain), Development (pengembangan), Implementation (implementasi), dan Evaluation (evaluasi). Dalam pelaksanaannya, penelitian ini dilakukan hingga tahapan pengembangan dikarenakan terbatasnya waktu. Panduan wawancara, kuesioner, serta lembar validasi ahli digunakan dalam penelitian ini. Terdapat dua ahli yang melakukan validasi terhadap purwarupa ini, yaitu ahli materi pembelajaran dan ahli media. Penelitian ini berfokus untuk mengembangkan sebuah media pembelajaran berbasis kecerdasan buatan dengan menggunakan hewan endemik Indonesia sebagai topik materinya. Terdapat 5 jenis hewan endemik yang digunakan dalam penelitian ini, diantaranya Komodo, Bekantan, Cendrawasih, Curik Bali, dan Maleo. Untuk mengetahui kebutuhan serta kesiapan siswa Sekolah Menengah Pertama yang berumur diantara 13-15 tahun, peneliti melakukan sebuah observasi awal dengan memberikan kuesioner untuk siswa di Kabupaten Badung, Provinsi Bali. Validasi ahli dianalisis menggunakan metode kualitatif dan kuantitatif. Angket validasi ahli dilakukan menggunakan sebuah kuesioner yang diisi oleh para ahli menggunakan skala Likert. Selain itu, para ahli juga memberikan masukan terhadap produk yang dikembangkan sehingga dapat menciptakan hasil yang lebih baik dari segi materi maupun dari segi media. Dalam proses validasi oleh para ahli, data dihitung menggunakan rubrik penilaian. Pada akhirnya, data tersebut dapat menunjukan apakah produk dikategorikan buruk, kurang baik, sedang, baik, atau sangat baik.

\section{TEMUAN DAN PEMBAHASAN}

Tujuan penelitian ini adalah menciptakan sebuah purwa-rupa produk media pembelajaran berbasis kecerdasan buatan yang memuat penjelasan/deskripsi fauna endemik Indonesia baik secara tertulis maupun oral untuk siswa kelas VIII SMPN 5 Mengwi. Dalam pengimplementasiannya, penelitian ini menggunakan metode penelitian dan pengembangan ADDIE, yang dimana dilaksanakan hingga dengan tahap development. Pada tahap awal, dilakukan proses observasi kepada 203 siswa berumur 13-15 tahun di wilayah Kabupaten Badung untuk mengetahui tingkat penggunaan teknologi siswa. Data menunjukkan bahwa 96.1\% siswa menyatakan 
kesiapannya dalam menggunakan teknologi dalam kehidupan sehari-hari. Namun sayang penggunaan teknologi dalam kehidupan siswa masih belum maksimal. Hal ini ditunjukan dari data yang diperoleh bahwa kegiatan yang paling sering dilakukan oleh siswa dengan teknologi internet adalah bersosial media. Oleh karena itu, kami merancang sebuah purwarupa yang dimana siswa dapat dimanfaatkan oleh siswa sebagai media pembelajaran Bahasa Inggris.

Pembuatan blueprint adalah hal selanjutnya yang dilakukan oleh para peneliti. Blueprint dirancang bersama dengan guru Bahasa Inggris dengan beracuan pada silabus yang digunakan di sekolah. Selanjutnya, blueprint ini digunakan sebagai dasar perancangan purwarupa produk penelitian. Produk penelitian ini dikembangkan oleh peneliti dengan bantuan dari sebuah tim programmers. Produk ini dikembangkan menggunakan sistem operasi Android. Terdapat 5 jenis fauna endemik Indonesia yang digunakan sebagai isian materi dalam media pembelajaran ini, yaitu Komodo, Bekantan, Cendrawasih, Maleo, dan curik Bali. Oleh karena itu, peneliti memilih nama AIClopedia untuk produk ini yang dimana berasal dari kata AI (Artificial Intelligence/Kecerdasan Buatan) dan Encyclopedia (Ensiklopedia). Dalam proses pengembangan program, waktu selama 3 bulan yang dibantu oleh tim programmers.

Selanjutnya, untuk meningkatkan kualitas dari produk yang dikembangkan, peneliti melakukan proses validasi ahli materi dan media. Terdapat 18 pertanyaan yang digunakan dalam masing-masing kuesioner validasi ahli. Kuesioner validasi ahli materi dan media menggunakan skala Likert. Dalam melakukan proses pengkategorian, peneliti menggunakan rubrik hasil penilaian validasi ahli, sebagai berikut:

Tabel 1. Rubrik Penilaian Validasi Ahli

\begin{tabular}{|l|c|}
\hline Nilai & Kategori \\
\hline $75.7-90$ & Sangat Baik \\
\hline $61.3-75.6$ & Baik \\
\hline $46.9-61.2$ & Sedang \\
\hline $32.5-46.8$ & Kurang Baik \\
\hline $18-32.4$ & Buruk \\
\hline
\end{tabular}

Validasi ahli pertama yang dilakukan adalah validasi ahli materi yang kemudian dilanjutkan oleh validasi ahli media. Validasi ahli materi dilakukan untuk mengetahui kualitas produk yang sedang dikembangkan dari segi materi pembelajaran. Sedangkan validasi ahli media dilakukan untuk mengetahui kualitas dari tampilan serta fungsional arsitektur sistem dari produk yang sedang dikembangkan. Berdasarkan data yang diperoleh pada validasi ahli pertama, produk 
dikategorikan sebagai produk yang sangat baik dari segi materi (77) dan juga media (78). Namun, data qualitative menunjukkan bahwa terdapat beberapa hal yang harus diperbaiki. Dari segi material, terdapat beberapa tata bahasa dalam kalimat yang harus diperbaiki. Disisi lain, dari segi media perlu adanya penyempurnaan seperti perbaikan di fungsi deteksi gambar yang tidak sesuai dengan deskripsi. Oleh karena itu, dilakukan proses revisi yang dilanjutkan dengan proses uji validasi kedua.

Tabel 2. Hasil Validasi Ahli Sebelum \& Sesudah revisi

\begin{tabular}{|c|c|c|}
\hline \multicolumn{2}{|c|}{ Sebelum Revisi } & Setelah Revisi \\
\hline Ahli Materi & $\begin{array}{c}77 \\
\text { (Sangat Baik) }\end{array}$ & $\begin{array}{c}84 \\
\text { (Sangat Baik) }\end{array}$ \\
\hline Ahli Media & $\begin{array}{c}78 \\
\text { (Sangat Baik) }\end{array}$ & $\begin{array}{c}85 \\
\text { (Sangat Baik) }\end{array}$ \\
\hline
\end{tabular}

Pengujian validasi ahli materi dan media dilakukan kembali setelah proses revisi dilakukan berdasarkan masukkan yang diberikan oleh para ahli. Seperti yang tertulis pada tabel 2, terdapat perubahan yang signifikan terhadap nilai yang diperoleh pada uji validasi, yaitu 84 pada uji validasi materi serta 85 pada uji validasi media. Sehingga produk yang diciptakan dapat dinilai sebagai produk yang memiliki kualitas sangat baik dari segi materi maupun media.

\section{Pembahasan}

Artificial intelligence atau kecerdasan buatan dari segi pengimplementasiannya di dunia pendidikan adalah sebuah sistem yang dirancang sedemikian rupa agar dapat membantu proses belajar mengajar (Holmes, Bialik, \& Fadel, 2019). Dengan dilakuikannya penelitian ini, diharapkan hasil produk dari penelitian dan pengembangannya dapat mengasah kemampuan siswa dalam melakukan proses pembelajaran mandiri (Haryanto, 2019; Kelly \& Heffernan, 2015; Murphy, 2019; Shin, 2018). Dalam sistem kecerdasan buatan, terdapat fungsi dimana sistem ini dapat digunakan sebagai tempat dimana siswa mempelajari materi pelajaran (Baker \& Smith, 2019). Siswa dapat mengakses pembelajaran dimanapun dan kapanpun saat mereka membutuhkan. Dalam produk ini juga terdapat petunjuk yang jelas tentang materi dan cara penggunaan sehingga siswa dapat melakukan pembelajaran secara mandiri.

Keerthiwansha (2018) dalam penelitiannya menemukan bahwa penggunaan sistem kecerdasan buatan dapat menciptakan proses belajar-mengajar yang lebih efektif. Dengan sistem kecerdasan buatan, performa guru dapat terdukung dengan baik karena adanya sistem yang dapat mengasistensi proses mengajar siswa. Guru dapat lebih berfokus kepada hal-hal fundamental lainnya seperti merancang 
pembelajaran dan metode pendekatan atau pengajaran yang akan diimplementasikan saat mengajar. Siswa dalam hal ini tidak perlu menunggu waktu bertemu langsung dengan guru untuk mendapatkan jawaban tertentu dari pertanyaan yang mereka miliki. Hal ini dikatakan dapat meningkatkan angka kepuasan siswa dalam belajar karena siswa mendapatkan respon yang cepat atas pertanyaan-pertanyaan yang dimilikinya (Klutka, Ackerly, \& Magda, 2018).

Selain itu Keerthiwansha (2018) juga menyatakan bahwa dengan adanya peran teknologi kecerdasan buatan di dalam proses pembelajaran akan menciptakan pembelajaran yang lebih aktif. Hal ini dikarenakan oleh pusat pembelajaran yang berada sepenuhnya pada siswa. Siswa melakukan kegiatan belajar atas niatan serta kebutuhan sendiri. Selain aktif, pembelajaran juga akan lebih menarik dengan adanya sistem kecerdasan buatan (Chassignol, 2018). Hal ini diakibatkan oleh adanya pengalaman berbeda yang dirasakan siswa saat menggunakan produk yang diteliti saat ini di dalam proses pembelajaran. Jika sebelumnya proses pengajaran dilakukan oleh guru dengan cara tradisional, sekarang proses pembelajaran akan dilakukan dengan cara baru menggunakan guru artificial/buatan. Berdasarkan dari studi literatur tersebut, dirasa perlu untuk melakukan penelitian yang dimana mengembangkan tentang sebuah media pembelajaran berbasis kecerdasan buatan.

Penelitian ini bertujuan untuk merancang sebuah media pembelajaran berbasis kecerdasan buatan yang dimana diharapkan mampu mendukung proses belajar deskriptif Bahasa Inggris siswa kelas VIII di SMPN 5 Mengwi. Produk ini diciptakan dalam bentuk aplikasi mobile yang dimana dapat diakses menggunakan sistem operasi Android. Pada tahap awal penelitian dilakukan observasi terhadap kesiapan siswa SMP di Badung dalam penggunaan teknologi. Ditemukan bahwa 195 (96.1\%) dari 203 orang siswa menyatakan kesiapan serta kedekatan mereka dengan penggunaan teknologi dalam kehidupannya sehari-hari. Bahkan ditemukan juga bahwa 178 orang diantaranya sudah memiliki ponsel cerdas pribadi. Hal ini didukung oleh hasil survey penggunaan TIK yang dilakukan oleh Kominfo (2017) menyatakan bahwa $82.63 \%$ siswa SMP di Indonesia terbiasa menggunakan teknologi dan internet terutama dalam hal penggunaan sosial media. Hal serupa juga ditemukan oleh Ofcom (2018), yang menyatakan bahwa 99\% anak berumur 12-15 tahun melakukan kegiatan daring dengan menghabiskan waktu sebanyak 20,5 jam per minggunya. Berdasarkan data tersebut, peneliti memutuskan untuk melakukan pengembangan dalam media pembelajaran berbasis kecerdasan buatan.

Penelitian ini tidak lepas dari peran serta guru Bahasa Inggris kelas VIII SMPN 5 Mengwi. Seperti yang telah diungkap sebelumnya, pada tahapan analisis guru mengisi daftar dari materi yang ingin ditampilkan dalam media pembelajaran yang dimana didesain menjadi sebuah blueprint materi. Hal ini dilakukan untuk memastikan materi yang disajikan sesuai dengan target kompetensi dan capaian siswa. Dari daftar yang diberikan, disimpulkan bahwa materi yang dipilih adalah 
bertujuan untuk mengajarkan siswa tentang teks deskriptif yang dimana menampilkan tentang hewan endemik Indonesia. Dikarenakan oleh keterbatasan waktu, dalam penelitian ini dipilih 5 jenis hewan endemik Indonesia. Adapun hewan endemik yang dipilih adalah Cendrawasih, Maleo, Komodo, Bekantan, dan Curik Bali. Hewan-hewan ini merupakan prioritas konservasi nasional Kementerian Lingkungan Hidup dan Kementerian Perencanaan Pembangunan Nasional/Badan Perencanaan Pembangunan Nasional Indonesia (Widjaja, 2014). Berdasarkan paparan tersebut, peneliti memutuskan untuk menamai media pembelajaran berbasis kecerdasan buatan ini dengan AIClopedia. AIClopedia berasal dari kata AI atau Artificial Intelligence (Kecerdasan Buatan) dan Encyclopedia (Ensiklopedia). AIClopedia dirancang dengan tujuan untuk dapat menjadi media pembelajaran Bahasa Inggris siswa yang dimana dapat menampilkan informasi mengenai hewan endemik Indonesia baik secara tulisan maupun oral. Diharapkan siswa dapat menggunakan media pembelajaran ini bukan hanya untuk meningkatkan pengetahuannya terhadap teks deskriptif dan hewan endemik Indonesia, namun juga kemampuannya dalam hal reading dan listening.

Setelah melakukan proses desain blueprint material, dilakukan proses validasi ahli materi. Hal ini dilakukan dalam tujuannya untuk memastikan kualitas materi baik yang berbentuk tulisan maupun suara yang terdapat dalam media pembelajaran AIClopedia. Dalam hasil nilai kuantitatif para ahli media, ditemukan bahwa kualitas materi dikategorikan memiliki kualitas yang sangat baik dengan nilai 77. Selain menilai secara kuantitatif dengan skala Likert, para ahli materi juga secara kualitatif memberikan masukkan dan komentar terhadap produk. Secara kualitatif, dapat disimpulkan bahwa masih terdapat kesalahan dalam isian materi dari segi tata bahasa, pemilihan kata, serta pronunciation dalam materi yang berbentuk suara. Oleh sebab itu, meskipun produk sudah dinyatakan memiliki konten materi yang sangat baik namun perlu dilakukan revisi untuk menyempurnakan hasil akhirnya.

Setelah melakukan proses revisi, peneliti kembali melakukan proses penilaian validasi ahli materi. Hal ini dilakukan untuk mengetahui apakah sudah ada peningkatan yang terjadi setelah dilakukan revisi. Dari data yang diperoleh, terjadi peningkatan secara kuantitatif dengan nilai perolehan 84. Dari angka tersebut dapat dikategorikan bahwa materi memiliki kualitas yang sangat baik. Selanjutnya secara kualitatif, sudah tidak ada komentar dan saran dari para ahli baik dalam segi materi berbentuk tulisan atau suara. Contoh dari revisi yang diberikan oleh para ahli materi dapat dilihat pada Gambar 1. 

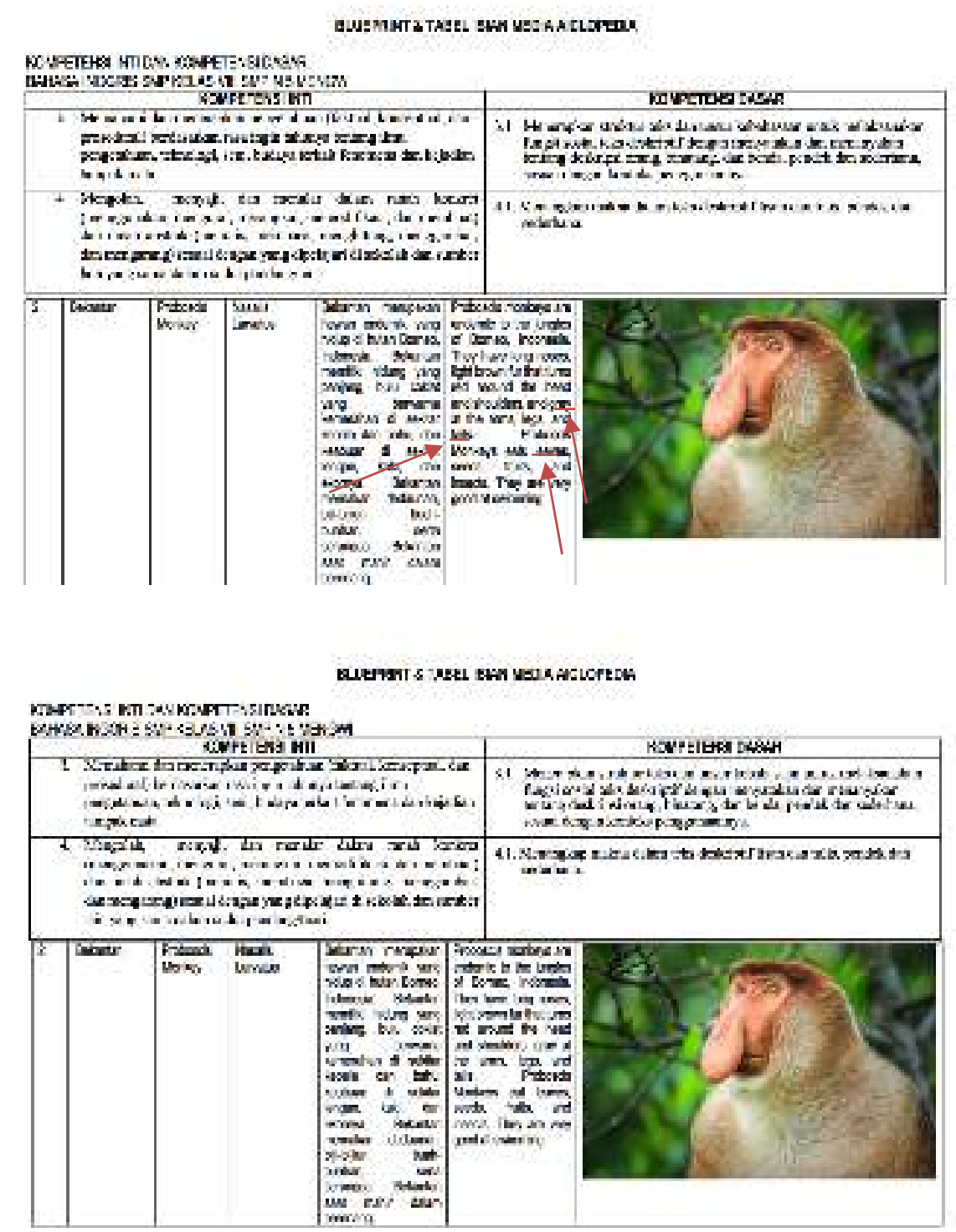

Gambar 1. Blueprint desain untuk materi

Dalam proses pengembangan atau pemrograman AIClopedia, peneliti dibantu oleh tim dari programmers. AIClopedia beroperasi dengan menggunakan teknologi pengenalan benda dalam sistem kecerdasan buatan. Produk purwa-rupa ini diharapkan dapat mampu membantu guru serta siswa dalam proses belajar mengajar dengan menyediakan informasi deskriptif tentang hewan endemik Indonesia baik secara tertulis maupun oral dalam Bahasa Inggris dan Bahasa Indonesia. AIClopedia dirancang untuk dapat mendeteksi hewan endemik Indonesia yang telah terdata baik dalam bentuk gambar maupun benda bergerak. Sehingga AIClopedia dapat digunakan dimanapun baik di dalam ruangan maupun saat melakukan kegiatan di luar ruangan.

Validasi ahli kedua yang dilakukan adalah validasi ahli media TIK. Hal ini dilakukan dengan tujuan untuk mengetahui kualitas produk dari segi media. Sama 
dengan validasi ahli materi, validasi ahli media dilakukan dalam 2 jenis yaitu kuantitatif dan kualitatif. Data kuantitatif diperoleh dari kuesioner yang dinilai menggunakan skala Likert. Sedangkan secara kuantitatif, terdapat saran serta komentar yang dimana menjadi bahan masukkan dan perbaikan bagi peneliti. Berdasarkan hasil dari validasi ahli ditemukan bahwa kualitas media TIK yang dirancang sudah dapat dikategorikan sebagai media yang memiliki kualitas yang sangat baik dengan nilai 78. Namun sayang, secara kualitatif masih ada hal yang perlu diperbaiki oleh para peneliti, contohnya perlu penambahan nama produk dan memasukan data email/media sosial siswa dalam halaman login. Sehingga perlu dilakukan proses revisi terhadap produk yang telah dirancang yang dimana dibantu oleh tim programmers.

Setelah proses revisi dilakukan, penilaian validasi ahli media TIK kembali dilakukan. Hal ini bertujuan untuk mengetahui peningkatan nilai secara kuantitatif dan kualitatif dari produk. Secara kuantitatif, data validasi menunjukkan angka 85 yang dimana produk dapat dikategorikan memiliki kualitas yang sangat baik dari segi media. Dari segi kualitatif, sudah tidak ditemukan lagi masukkan atau komentar dari para ahli. Untuk contoh dari revisi yang diberikan dapat dilihat pada Gambar 2 dan Gambar 3.

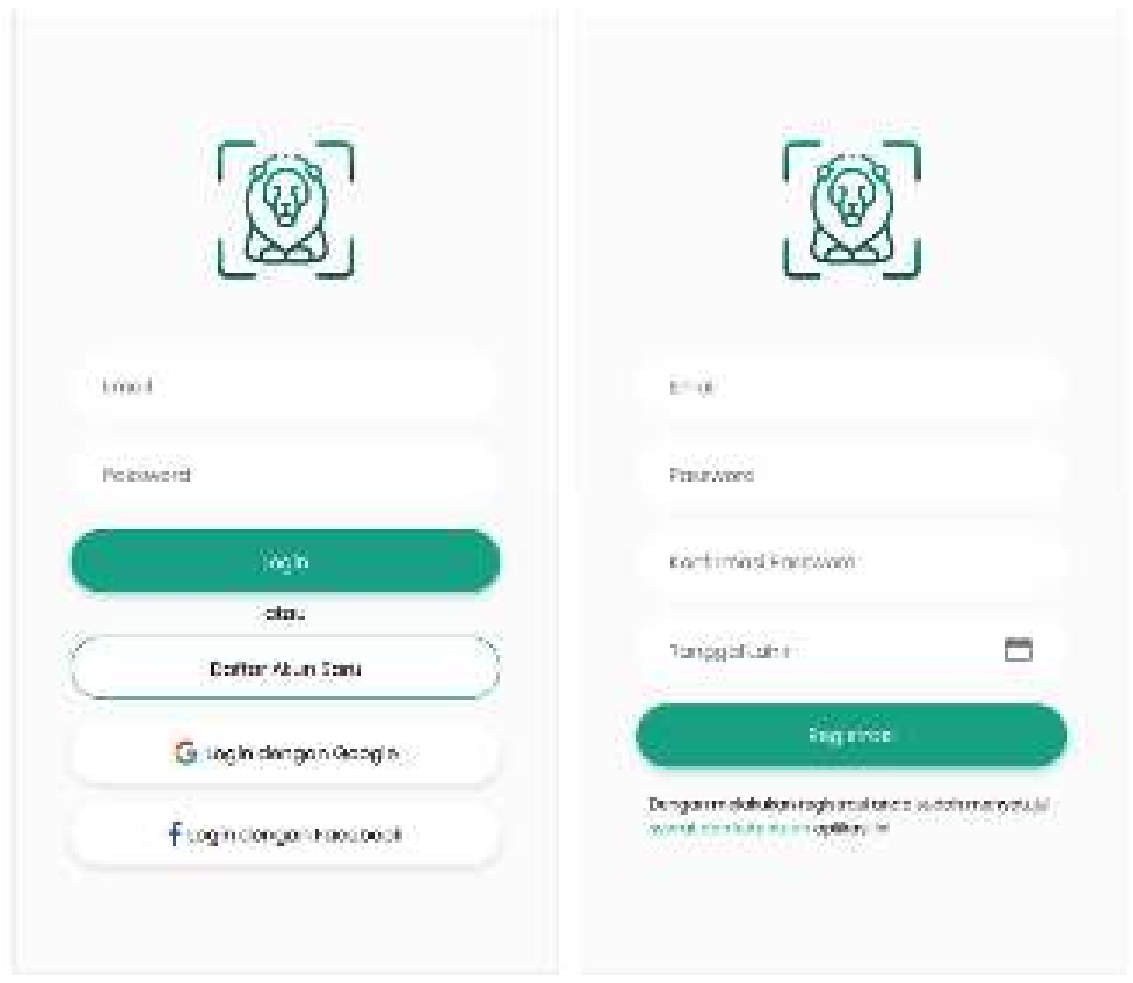

Gambar 2. Tampilan Media Sebelum Revisi 


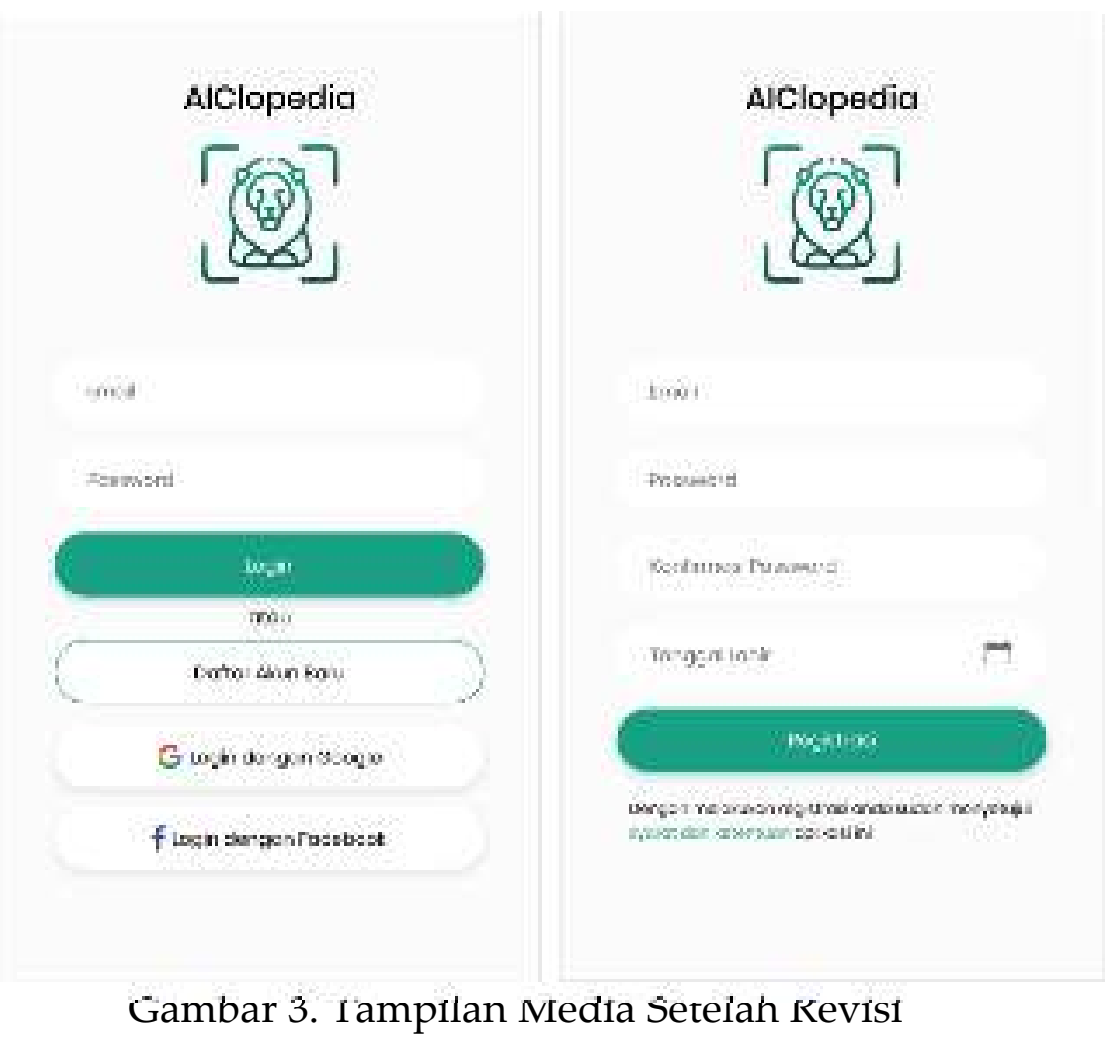

\section{KESIMPULAN DAN SARAN}

\section{Kesimpulan}

Penelitian ini menggunakan metode ADDIE yang dimana bertujuan untuk mengembangan sebuah produk purwa-rupa media pembelajaran Bahasa Inggris berbasis kecerdasan buatan untuk siswa kelas VIII SMPN 5 Mengwi. Produk yang diciptakan diberi nama dengan AIClopedia. Produk ini diharapkan mampu digunakan sebagai media pembelajaran berbasis kecerdasan buatan yang dalam pengimplementasiannya dapat memberikan informasi deskriptif hewan endemik Indonesia dengan menampilkan dwi-bahasa yaitu Bahasa Indonesia dan Bahasa Inggris baik dalam bentuk lisan maupun oral.

Pada akhir studi, dilakukan proses penilaian validasi ahli. Adapun validasi ahli yang dilakukan adalah dari segi ahli materi pembelajaran dan ahli media TIK. Adapun tujuan dari kedua validasi ahli tersebut dilakukan adalah untuk mengetahui kualitas dari produk yang dikembangkanl. Data akhir yang diperoleh menyatakan bahwa produk yang dirancang dapat dikategorikan sebagai produk dengan kualitas sangat baik. Adapun angka perolehan akhirnya adalah ahli materi pembelajaran 84 , serta ahli media TIK 85. 


\section{Saran}

Penelitian ini jauh dari kata sempurna dan butuh banyak perkembangan lain yang dapat dilanjutkan pada penelitian berikutnya. Sebab oleh terbatasnya waktu yang dimiliki oleh para peneliti, penelitian dilakukan hanya sampai dengan tahap pengembangan. Oleh karena itu, penelitian di masa yang akan datang dapat melanjutkan penelitian hingga tahapan evaluasi. Selanjutnya, oleh karena keterbatasan waktu pula AIClopedia memuat informasi hewan endemik Indonesia yang jumlahnya sangat terbatas. Diharapkan penelitian selanjutnya dapat menambahkan jumlah hewan endemik Indonesia yang dapat direkognisi dengan menggunakan teknologi kecerdasan buatan. Subjek dari penelitian kedepannya juga butuh untuk diperluas karena pada studi ini peneliti hanya terfokus pada pengembangan media pembelajaran untuk siswa kelas VIII SMPN 5 Mengwi.

\section{UCAPAN TERIMA KASIH}

Peneliti mengucapkan terima kasih kepada Kementerian Riset dan Teknologi/Badan Riset dan Inovasi Nasional Republik Indonesia yang telah mendukung penelitian ini melalui program Penelitian Dosen Pemula tahun 2020. Mereka juga sangat berterima kasih atas komitmen guru serta partisipan lain yang terlibat dalam penelitian ini.

\section{DAFTAR PUSTAKA}

Aristides, Y., Purnomo, A., \& Samekto, F. A. (2016). Perlindungan Satwa Langka di Indonesia dari Perspektif Convention on International Trade in Endangered Species of Flora and Fauna (Cites). Diponegoro Law Journal, 5(4), 1-17.

Baker, T., \& Smith, L. (2019). Educ-AI-tion rebooted? Exploring the future of artificial intelligence in schools and colleges. Retrieved from Nesta Foundation website: https://media.nesta.org.uk/documents/Future_of_AI_and_education_v5_WEB. pdf

Chassignol, M., Khoroshavin, A., Klimova, A., \& Bilyatdinova, A. (2018). Artificial Intelligence trends in education: a narrative overview. Procedia Computer Science, 136, 16-24.

Deloitte. (2019). Global development of AI-based education. China: Deloitte

Fahimirad, M., \& Kotamjani, S. S. (2018). A Review on Application of Artificial Intelligence in Teaching and Learning in Educational Contexts. International Journal of Learning and Development, 8(4), 106-118.

Haryanto, E., \& Ali, R. M. (2019, January). Students' Attitudes towards the Use of Artificial Intelligence SIRI in EFL Learning at One Public University. In International Seminar and Annual Meeting BKS-PTN Wilayah Barat (Vol. 1, No. 1). 
Henriksen, D., Mishra, P., \& Fisser, P. (2016). Infusing creativity and technology in 21st century education: A systemic view for change. Educational Technology \& Society, 19(3), 27-37.

Holmes, W., Bialik, M., \& Fadel, C. (2019). Artificial intelligence in education. Boston: Center for Curriculum Redesign.

Ma, W., Adesope, O. O., Nesbit, J. C., \& Liu, Q. (2014). Intelligent tutoring systems and learning outcomes: A meta-analysis. Journal of educational psychology, 106(4), 901.

Keerthiwansha, N. B. S. (2018). Artificial Intelligence Education (AIEd) in English as a Second Language (ESL) Classroom in Sri Lanka. Artificial Intelligence, 6(1), 3136.

Kelly, K., \& Heffernan, N. (2015, June). Developing Self-regulated Learners Through an Intelligent Tutoring System. In International Conference on Artificial Intelligence in Education (pp. 840-843). Springer, Cham.

Klutka, J., Ackerly, N., \& Magda, A. J. (2018). Artificial Intelligence in Higher Education. Current Uses and Future Applications. Louisville. Learning house.

Kominfo, K. (2017). Survey penggunaan TIK 2017 serta implikasinya terhadap aspek sosial budaya masyarakat. Pusat Penelitian dan Pengembangan Aplikasi Informatika dan Informasi dan Komunikasi Publik, Kominfo RI.

Murphy, R. F. (2019). Artificial Intelligence Applications to Support K-12 Teachers and Teaching: A Review of Promising Applications, Opportunities, and Challenges. Perspective. RAND Corporation.

Ofcom. (2018). Children and Parents: Media Use and Attitudes. London, UK: Office of Communication.

Rastati, R. (2018). Media Literasi Bagi Digital Natives: Perspektif Generasi Z di Jakarta. Kwangsan, 6(1).

Shin, M. H. (2018). How to use artificial intelligence in the English language learning classroom. Indian Journal of Public Health Research \& Development, 9(9), 557561: self efficiacy.

Tapscott, Don. (2013). Grown Up Digital: Yang Muda Yang Merubah Dunia. Jakarta: Gramedia Pustaka Utama .

Widjaja, E. A., Rahayuningsih, Y., Rahajoe, J. S., Ubaidillah, R., Maryanto, I., Walujo, E. B., and Semiadi, G. (2014). Status Kekinian Keanekaragaman Hayati Indonesia (1st Edition). Jakarta: LIPI Press. 